\title{
VAKIFLAR AND GUILDS AS AN INSTITUTION OF COMPLEMENTARITY
}

\section{Dr. Ali DEMIR*}

\begin{abstract}
In Ottoman Empire cosmology was integrated with theology in the religious orders. Temporally and socially their descent goes hand in hand with the rise of the guilds. This coexistence of vakuflar and guild explained with the ideal type method of Weber with the two different type of social coordination, which are integration and inclusion. An integration based on the community norms could be achieved by generalizing the interest of the ethical and/or ethnic leader in vakuflar. On the other hand, inclusion within an organization of an instrumental rationality is expected less from historical personalities and more from the modern legal system on the basis of the contract. Within the Ottoman Empire, the most crucial actors of the transition from a community based on vakuflar to a society based on the symbolic communication inside guilds are the ayans. Ayans would need both integration through norms and inclusion through power and money. The coordination of these two types of social action is called complementarity. Following an examination of the preconditions of modernity, the article offers a theoretical frame for these change of form on the institutional level.
\end{abstract}

Keywords: Vakıflar, guilds, integration, inclusion, complementarity, ideal type

\section{TAMAMLAYICILIK KURUMU OLARAK VAKIFLAR VE LONCALAR}

\section{$\ddot{\mathbf{O z}}$}

Kozmoloji ile teoloji Osmanlı İmparatorluğu'nda dini dergâhlarda birbirine entegre edildi. Bu dergâhların ve üzerinde kuruldukları vakıfların sosyal ve zamansal gerilemeleri, loncaların yükselişi ile ele ele gider. Çalışmada vakıflar ve loncaların bu eşzamanlılığı Weber'in ideal tip yöntemiyle iki farklı sosyal koordinasyon türü olarak işlenmektedir, bunlar ise entegrasyon ve dahil etmedir. Toplumsal normlara dayalı entegrasyon, vakıfların etik ve/veya etnik liderin çıkarlarını genelleştirmeye yetebilir. Ancak, loncalar gibi araçsal akıl üzerine kurulu bir organizasyonda birliğe dahil etme, tarihsel kişiliklerden çok sözleşme temelinde modern hukuk sisteminden beklenmektedir. Osmanlı İmparatorluğu'nda, vakıflar merkezli bir topluluktan loncalar çerçevesinde sembolik iletişime dayanan bir topluma geçişin en önemli aktörleri ayanlardır. Ayanlar hem bağlayıcı normlar yoluyla entegrasyonu hem de güç ve para yoluyla dahil edilmeyi talep ediyorlardı. Bu aynı anda iki tür sosyal eylemin koordinasyonu tamamlayıcılık olarak tanımlanacak. Çalışma, bu bağlamda modernitenin önkoşullarının incelenmesinden sonra, bu biçim değişikliğine kurumsal düzeyde teorik bir çerçeve sunmaktadır.

Anahtar kelimeler: Vakıflar, loncalar, entegrasyon, dahil etme, tamamlayıcılık, ideal tip

*Zürich Üniversitesi, Araştırma Makalesi

Makale Giriș Tarihi:12.03.2021
ORCID: 0000-0002-7955-0085

Sayfa Sayıs1: 779-799

Makale Kabul Tarihi: 16.05.2021 alidemirden@gmail.com

Makale Yayın Tarihi: 05.08.2021 


\section{Introduction}

Today there is a factual emergence not only of religious communities, in the sense of orders (dergâh), but also of vakıflar under new conditions (Kuran: 2016c: 436; Akçay, 2019: 59; Ozil, 2019: 215). Orders and the vaklflar are two different institutions, as well as merge them, since vakıflar have been the economic basis of all stable orders during the Ottoman Empire. Indeed, the discourse on vakuflar has a long-standing tradition, why they have been well studied (Köprülü, 1938: 5; Uzunçarş1l1, 1941: 277; Barkan, 1942: 280; Kayaoğlu, 1978: 50; Heper, 1980: 83 Hoexter, 1998: 476; Morgan, 2001: 22; Akgündüz, 2002: 450; Singer, 2008: 18; Bulut and Korkut, 2016: 24; Ahbab, 2017: 51). But, they have been neither well studied from the point of view of their function as an organization of a particular society with the corresponding economic system, and nor typified in their function with similar organizations and compared at the same time. From an organizational sociology perspective, vakuflar and guilds are different organizations with similar function. They are similar in their function, but they differ in terms of their structure and objective.

\section{Vakıflar and Ayans}

To begin with, it is well worth remembering that vakuflar guided by dervishes and guilds led by professionals in the Ottoman Empire has structural differences not only with each other but also with the European orders and guilds. Guilds in the Ottoman Empire are a mixture of the organization of patrimonial monopolization of rare resources and networks of a new type of communication. They have not successively disappeared in the transition to modern societies, nor have they assumed a folkloric function, as in Europe. On the other hand, compering to Europa vakıflar as the lands and institution of Islamic orders have not been transformed into trusts during the transition to nation states (Schoenblum: 1999: 1191; Ozil, 2019: 220). In that context, it should also be remembered that (a) the legitimation of Ottoman rule in the 20th century continued to be based on sacred foundations, that (b) the country continued to belong institutionally to Almighty God, that (c) patriarchal structures in the sense of Max Weber prevented economic monopolies, and (d) that there was no private property freed from political power, even though there were marketeconomy organized and coordinated in state structure and companies (Weber, 1980a: 580-624; Saraçoğlu, 2015: 63; Nizri, 2015: 39).

On the organisational level, while the most important actors in the in the foundation, establishment and management of the Ottoman Empire were the dervishes, the ayans are establishing themselves as the actors of modernity. While dervishes legitimized their actions with the religious aura and for a place in the afterlife, Ayans enforced themselves with the money power. It is well known that money power prevails in every sphere of life and also forces it to reorganize itself according to its logic (Weber, 1980a: 795). The dervishes, as the actors of the integration based on religion, land and state, met in vakiflar, which were cultivated by peasants. On the other hand, with the advent of capitalism, the main actors were not the peasants, but the professionals, workers, traders and employers. And these did not meet in vakfflar, but in the guilds. At the same time vakıflar and guilds were comparable in their functions. Like vakıflar, guilds also assume multiple functions in society. Both can be defined as a form of an organizational unit in which, as Parsons would put it, ego's expectations of age wishes are bundled (Parsons, 1951b: 3; Parsons, 1960c: 471, 482). In contrast to vakıflar, where belonging was based on internalised norms through 
socialisation but within the structure of orders, the guilds are closer to the today's employer and employee organizations. Guilds are organized and differentiated according to social differences based on merit, achievement rather than God-given diversity based on ascription.

\section{Ideal Type}

Before moving on into the research question, hypothesis, and into the details, we shall first introduce the method that will guide the discourse. This is the ideal type method by Max Weber (Weber, 1985b: 190). The method is based on the idea that the meaning and content of concepts such as vakfflar, organisation, capitalism, stability, transformation can hardly be defined independently of time, space and the interests of the respective actors (Weber, 1986c: 537). At the same time, an essential function of science lies in the simplification of complex facts, in showing the diversity of phenomena in their unity and, if possible, ,sense adequacy“, in understanding from the viewpoint of the actors himself (Weber, 1980a: 9).

„It [the ideal type] is an image of thought which is not the historical reality or even the ,actual' reality, which is much less there to serve as a scheme into which reality should be classified as an exemplar, but which has the meaning of a purely ideal boundary concept against which reality is measured for the clarification of certain significant components of its empirical content, with which it is compared. Such concepts are entities in which we construct connections using the category of objectiv possibility that our imagination, oriented and trained to reality, judges to be adequate.“" (Weber, 1985b: 194)

Ideal types, in other words, are constructed to capture empirical reality in a theoretically optimal realization. Ideal types are the interpretive schemes that show an end-states of a development proceeding under ideal conditions (Parsons, 1937a: 604). Ideal types are a model that points to what can be realized in principle in a majority of cultural phenomena. The advantage of the ideal type model is that, in contrast to a comparative method, the ideal type method leads to a hierarchy. The disadvantage is that they cannot be empirically falsified because they are a thought construct. At the same time, the method can level the tension between theory and empiricism (Habermas, 1981a: 276, 412).

\section{Research Question and Hypothesis}

Based on that very ideal type method, we first distinguish between integration and inclusion on the theoretical level and vakuflar and guilds on the sociological level. Integration and inclusion represent two ideal type of social and functional bounding (Lockwood,1964: 373; Luhmann, 1997e: $618,739)$. Compare to inclusion is integration norm based type of coordination. On the other hand, inclusion can be achieved for example on a structural level by a differentiation between central and periphery, type of federal structures and/or principal and subsidiary without a reference to higher norms, whereas integration need a socially bond norm (of legitimation) for that very functional differentiation and belonging.

Then, according to this theoretical distinction, the historical-empirical phenomena are matched to the respective ideal type. From this point of view, the orders based on vaklf estate have not only an intrinsic sense for the normative order of the Ottoman Empire, but they were also able to preserve themselves until the emergence of modernism. In the course of history, the religious orders as a unit of belonging declined at the same time as the decline of vakuflar as a type of estate and the Ottoman Empire itself. The implosion of the Ottoman Empire gave rise to a number of nation states in which the increase in complexity triggered by social differentiation was absorbed. 
Compare to kingdom national states represent a differentiation of organization and of identity on the basis of ethics, rights, ethnicity and languages (Anderson, 1983: 16, 32, 42; Habermas, 1999e: 130).

On the other hand, the question of what form the orders and vakıflar took during this conversion within the nation states has not yet been posed. Since especially the factual existence of guilds and the orders, some of which could preserve themselves without an official acknowledgment until the foundation of the modern Republic of Turkey, and after that they kept themselves despite a general prohibition of religious orders (Faroqhi, 1976a: 183; Faroqhi, 1981b: 110), is in need of explanation, the question arises whether this paradox can be explained from an organizational-sociological perspective with the evolution, transformation, change of form, and from a philosophical perspective with the emergence of modernity, in which integration and inclusion is achieved at the same time (Habermas, 1981a: 119, 222, 257; Luhmann, 1993c: 240; Luhmann, 1997e: 134, 413, 622). Within nation states as modern types of purpose-driven structures, social belonging is achieved simultaneously through integration and inclusion. Nation states achieve integration through the social norm of community and inclusion on the basis of communications media like money, power and function.

Within these sociological considerations the question arises whether not only the coexistence of institution like vakıflar and guild, but also the two corresponding type of coordination (integration and inclusion) can be explained with a new type of joint bonding, which is complementarity. Before explaining the complementarity, these two types of coordination (integration and inclusion) in the sense of Weber's ideal type can be used to explain both the stability of society despite changes with the same functioning of the corresponding institution (vaklflar and guild), as well as their transformation during the period of social development with the corresponding mindset of pre-modern and modern society (pre- and modernity). Weber's assumption of the cultural foundations of the development of social modern system with the corresponding mindset, institution and actors is in favour of these assumption. According to Weber's Protestant thesis, capitalism owes a political program anchored (religiously) in society (Weber, 1986c: 163). This program, consisting of capitalism, liberal democracy, constitutionalism, and individual autonomy, can be subsumed under the concept of modernity and analysed in sociology either with social and system integration, or inclusion (Habermas, 1998d: 99; Habermas, 1981b: 229; Luhmann, 1997e: 619, 739). Since this program stalled in the Ottoman Empire or was prevented from unfolding by rule, but the institutions adapted to the capitalist conditions of production contrary to the political norms of rule, the question arises whether this change and simultaneous existence for a need for integration and inclusion can be explained with the term of complementarity, without a direct, strong link to the society (Luhmann, 1997e: 112, 828). The coexistence of these two interlocking types of coordination is addressed under the concept of complementarity.

The assumption here is that this transition from vakiflar to the guilds represent two type of coordination mechanism operating with its own logic. From a normative standpoint and especially since according to the Islamic-Ottoman world view the idschtihâd gates were closed, everything had to correspond to the principle of tradition (kanûn-u kadîm), the social opening has to be achieved by the idea of preservation despite new conditions (Berkes, 1964: 11). Transformation in the sense of evolution was the only legitimised way for change. Accordingly, with the advent of 
modernity, as the empire transformed itself in the nation states, so were religious orders within the nation state transformed on the organizational level. This is the reason why we observe guilds as the place of solidarity in addition to vakiflar. While vakuflar were the place of diversity, in guilds the equals have solidarized with each other. The emergence on the organizational level will be made plausible first in the genesis of vakuflar, second in their functional similarity with the guilds in the Ottoman Empire, and then in a comparison between Ottoman and European guilds. After an intermediate reflection, the concept of complementarity is proposed for the mediation of these two different types of coordination and corresponding institution.

\section{Two Type of Vakıflar}

The history of the vakuflar is intertwined with the of the religious orders (dergâh) (Hoexter, 1998: 474; Morgan, 2001: 21; Singer, 2008: 107; Luz, 2014: 108). They represented a system of order that was complex enough in its form to be able to develop and unfold in society as a whole, while at the same time absorbing social complexity. Dergâh were founded on a vakıf, order property, why they were also called vakıf. Sociologically the orders must be distinguished on the one hand from the vakiflar as religiously legitimate ownership of common goods and on the other hand from the vakfflar as an organizational unit in the sense of a purpose-rational enterprise, although both are known under the same name, namely vakıf (Turkish, plural vakuflar) and waqf (Arabic, plural $a w q \bar{a} f)$. The first type of $a w q \bar{a} f$ "can be seen as an institution that, even if sinful, one day promised people liberation from hellfire" (Çizakça, 2019: 74). These $a w q \bar{a} f$ had on this world the function of a form of taxation that had the zakât system before the advent of Islam and also during the early phase of Islamic rule (Demir, 2017: 76). The word waqf does not appear in the Koran. On the other hand, zakât, the benefaction, belongs to one of the five pillars of Islamic ethics. In this respect, the broad institutionalization of waqf owes its existence to the religious demand for integration, which was raised politically by questioning the existing ownership of the kings (Habermas, 1998d: 177; Weber, 1980a: 456). The second type of $a w q \bar{a} f$ is derived from the first type, for which they were first desacralized after the reign of Prophet Muhammad. The desacralization goes back to the fact that the system had to be rationalized with the expansion of Islamic rule and put more strongly into a motivational context with the conquest of land and cultivation in the name of God. Despite a reference to God as a basis of religious legitimacy, this type of awqāf had to be established, maintained and defended not only by, but also for the profane means (Mundy and Smith, 2007: 49). For that very reason Kuran described it as follows: "In the premodern Middle East, from 750 C.E., perhaps even earlier, an increasingly popular vehicle for the provision of public goods was the waqf, known in English also as an 'Islamic trust' or a 'pious foundation.' A waqf is an unincorporated trust established under Islamic law by a living man or woman for the provision of a designated social service in perpetuity" (Kuran, 2001b: 842).

They were firstly programmed to integrate all ethnic groups under the condition of a Muslim identity (Kafadar, 1995: 63, 153). Vakıflar represents during the foundation and establishment of Islamic and Ottoman rule the organizational basis for the bundling and distribution of scarce goods (Mundy and Smith, 2007: 10; Kuran, 2016c: 444; Barakat, 2015: 113). They "were appropriated by the central government" for the role of "centralizing efforts" exactly thanks their decentralized structure (Van Leeuwen, 1999: 87, 115). This aggregation can be seen on the level of the actors in the fact that the dervishes were considered as the founders and administrators of vakuflar at the same 
time as the bearers/disciples of the moral of the Prophet Mohammad. The dervishes were also represented in the founding, establishment and expansion of the Ottoman Empire, both in the army and in the state leadership, and formed the most important part of its spiritual elite (ulema) (Kafadar, 1995: 19).

Luhmann would see in vaklflar first apparency the symbiosis, the material formation of the meeting of personality, morality and organization (Luhmann, 1997e: 378). They represent a unity of norm and organization. In this respect, vakuflar is one of the first organizational units in which morality in the sense of mainly religious view of man, was brought together with personality and society. But in vakuflar as an organization for rational purposes legitimized under modern conditions and law (Weber, 1988d: 506; Hannah, 1992: 46; Luhmann, 1997e: 24, 414; Luhmann, 1993c: 121), not in the leadership of dervishes but of ayans was the relationship between ends and means decouple by beginning to derive the meaning of their actions from the means of the organization itself (Luhmann, 1972a: 32). Vaklflar had for the actors of the transition phase to modernity (dervishes, janissaries, professionals, trader, minority members, ayans) not more the function of integration, but the most important organizational basis for the demand for social inclusion based on law and function (Karpat, 1972a: 244). Together, these actors demand property rights and functional equality according to the modern legal system. What the dervishes have in common with ayans is that both actors have earned their livelihood from vakuflar. The difference, on the other hand, is that while the dervishes received vakuflar for their living after a won war and only administered it in the name of God, the ayans have promoted the cultivation and ownership of the same states no longer a means to an end, but the end itself. Ayans wanted with the emergence of modernity to possess vaklflar under legal guarantees.

Ayans could organize vaklflar as a new type of institution, in which purposeful action should be legitimised not more under religious guidelines according to the method of analogy, but with abstract principial and norms of modern law (Weber, 1988d: 510; Hannah,1992: 46; Luhmann, 1997e: 363, 460; Luhmann, 1993c: 121, 324). This has far-reaching consequences; the land of Almighty God becomes the property of the individual, at the centre of whose interactions was not the sacred ends, but the profane business. This changes the organizational foundations of the social order, which is no longer sought in the community, in the clan, in the vakuflar as institutions of diversity, but in the economically conditioned market, where social differences are the very foundation of social inclusion. This new order also affects the logic of belonging and identity; instead of the quality of the person considered innate, they depend on their profession, property, memberships to an organization. Both are coordinated according to the principles of modern law in jointly elaborated social contract in society and statutes in organizations.

\section{The Rise of Ayans}

In order to explain the transformation and transition, it should first be pointed out that in the Ottoman Empire the social structure was originally structured according to the sacral above/below, ruler/ruled scheme. At the same time and over time, the state was organized territorially according to the differentiation of centre and periphery (Heper, 1980: 96; Luhmann, 1997e: 664; Barkey, 1994a: 320). The centre was coordinated by the internal differentiation of the bureaucracy (babi $-l$ ali) into clergy (ulema) and army (askeri) (Mardin, 1969a: 259). Both groups were recruited, rationalized and held together in solidarity by the principle of the unity of religion and state (din- $u$ 
devlet) in the recruitment system (Mardin,1992b: 85; Quataert, 2000: 156). In this respect, the goal remained unity, which was understood as centralization and unification. This is one reason why the distinction between public and private sphere was abolished in the palace of the Sultan: his empire was also his home (harem) (Peirce, 1993: 3). This norm based integration was in the Ottoman Empire only reserved for the Sultan. Only in his case was oikos (harem) also functionally the same place as polis (state) (Arendt, 1992: 40, 191). This structure was able to offer a stable order, orientation until a new, intermediary social class emerged in the periphery as a result of the developments in technology and the unfolding of the systemic media like money, power and right, which demanded a new form of system and social integration, a new logic of coordination, namely inclusion. Compare to the concept of integration an action according to inclusion based on function rather than on structure and inclusion is less norm (of religion) driven and much more concern with the idea of coordination by modern law.

The representatives of this new social system of coordination were called ayan. The term ayan was derived from the Arabic a yan and means "friends of the Prophet". According to Sadat, the term was first used in the Ottoman war against Austria around 1639-1699 in the meaning of notables. "At that time, the term ayan was used to refer to certain wealthy individuals, elected by the people, who acted as intermediaries between the local populace and officials of the Porte, especially in matters of finance, taxation, and military recruitment" (Sadat, 1972: 346). The state should have defined them as "known, honest, and wealthy, and whose words were listened to by the people" (Heper, 1980: 87). In the beginning, ayans were the members of the clergy, some of whom were promoted by the central power. (Karpat, 1972a: 52; Matuz, 2010: 86). The power of this new social class grows proportionally with the decline of the Ottoman Empire; the beginning of its rise begins with the agreements of Karlofça (1699) and Pasarofça (1718). "The outbreak of the war with Russia in 1768 finally forced the Porte to recognize the existence of the ayan, granting them official status in exchange for otherwise unobtainable men and supplies" (Sadat, 1972: 351). At the organizational level, the Ottoman life had until then mainly taken place within the structures of vakıflar.

A vaklf provided both the economic-political basis of a rational organization on the principle of differentiation, as well as the place of normative integration of diverse ethnic groups and ethics. In this respect, it is no coincidence that the beginning of the end of the Ottoman Empire was also the beginning of the departure of the Islamic vakıflar system. This correlation can be seen well in the collapse of the tımar lands, which were administered by holders of vakıflar as an institution of integration (Matuz, 2010: 175). According to Karpat, in 1653 there were 5618 tımar estates in the city of Erzurum. This number drops to 3575 in 1804, whereas the number of regular kaplkulu soldiers was around 12800 in 1475, rising to 92206 in 1630 (Karpat, 2009c: 50). To interpret this decline, it must first be noted that because the tımar estates were also distributed according to the principle of loyalty, the tımar owners were less dependent on the farmers or the agricultural market, but more dependent on the central state (Barkey, 1996b: 463). Second, at the end of the 16th century, vakıflar was recognized as a quasi-private property (mülk) in exceptional cases and removed from the control of the bureaucracy, namely the legal instance (kadl) (Sadat, 1972: 349). Consequently, in the 18th century the sons of a deceased clergyman could de facto inherit his lands. Faroqhi also points out that the son of such a clergyman must have successfully maneuvered until he actually possessed his father's inheritance and could now transform himself into an ayan 
(Faroqhi, 1981b: 111). In this process of recognition, transformation and transition, the norm until modernity was not the contract law based on right, but the loyalty to the recognizing ruler.

On the organizational level, the decline of the tımar lands mainly harmed the ruling centre, because the state had to pay much more soldiers and at the same time had to expect less taxes from the periphery. In this process, the cavalry (sipahiler), as the centre's weapon power, lost its position as administrator of the lands. The function of the public goods, vakuflar also changed: they no longer served the needs of the peasants, but became the source of cash for the ayans through their taxation by passing them on to peasants. "On the one hand, they must possess 'access' to authority, and so be able to advice, warn, and, in general, speak before the authorities on behalf of the society or some part of it. On the other hand, they must have social power of their own, which is not dependent on the ruler, and which gives them a position of acceptance and "natural leadership"" (Heper, 1980: 87) In view of this development, the central state had to formally recognize the power of the ayans by upgrading their status (Karpat, 1972a: 223; Karpat, 2009c: 54).

Functionally, this new intermediary position could no longer be imposed on the structures of vaklflar. As an institution of integration were they linked to the existing system of land and military rule by a strong structural link based on norm of religious origin (Luhmann, 1997e: 100, 199, 336, 344). What was needed was a new form of organization that would obey economic logic instead of religiose norms and/or direct political order. This is indicated by the simultaneity of the rise of the ayans and the collapse of the Ottoman land and military system, as a result of which the peasants now (a) subjected themselves directly to a powerful ayan for their security, (b) migrated to the cities for paid labour, or (c) rebelled (Heper, 1980: 86; Barkey (1994): 165; Barkey, 1996b: 476; Akdağ, 1999: 108). "To the ayan, a state of controlled and modulated anarchy was essential both to maintain their intimidation of the peasantry and sustain their independence of action against the central government. If the peasants were the victims, the merchants were the natural allies of the ayan" (Sadat, 1972: 354). Sadat continues: "As long as the ayan were able to fulfill their function of supply and protection, they and the merchants shared a communality of vested interests. While one prospered, the other thrived" (Sadat, 1972: 355).

Thanks to their new position, the ayans received the exclusive right to collect taxes (iltizam) and thus became the controlling body over the associated lands (Quataert, 2000: 48; Karpat, 2009c: 232). With this new constellation, they not only became de facto the only rulers of their region, but also formed new alliances through trade with Europe. The volume of trade increased from 4.4 million pounds in 1783 to 12.2 in 1845 and 54 in 1876 (Karpat, 2009c: 53). Through trade with Europe, the upper class of farmers rose to become landowners and small traders who began to produce for the market. Some ayans became manufacturers and middlemen; but there were also those who, like Mehmet Ali Pasha in Egypt, became statesmen. Or they became freedom fighters, as illustrated by the example of Tepedenli Ali Pasha, who was appointed by the Sultan in 1788 as governor for the Sancak Janina and soon had a private army and his own fleet (Karpat, 2009c: 56).

The maxims of the actors in this phase are less and less determined by sacred, religious norms, rule-centred politics and increasingly by symbolic communications media, like power, property and money (Luhmann, 1997e: 336; Baldwin, 1971: 580). This new order was institutionalized with the Sened-i Ittifak Agreement (1808) in a new form of social belonging, namely through social contract law. The treaty Sened-i Ittifak is called the Magna Charter of the 
... (akademik, hakemli, indexli, uluslararası dergi)

Ottomans (Rumpf, 1996: 37; Heper, 1980: 89). Historically, this achievement was initiated by an ayan: Alemdar/Bayraktar Mustafa Pasha. Not the bare force of arms, but the symbolic threat of the forces pushes the sultan to sign. As emphasized in the introduction of the agreement, the key issue was the legal adaptation of the new socio-economic conditions between the central state and the leaders of the periphery, i.e. the ayans. In this social contract, the central state recognizes the power of ayans as a new elite with an intermediary power. The empire also undertakes to act only in accordance with the principles of law supported by both sides. The ayans received from the Sultan the legal recognition of their property and inheritance rights, as well as the claim that they are representatives of the people. "It [Sened-i İttifak] legitimized the status of the ayans in relation to the throne and the people, not on the basis of Islam but of power" (Karpat, 1972a: 254).

Sened-i Ittifak initiates also the Tanzimat phase (1839-1878), in which a series of reforms were continued. The first Ottoman constitution (Kânûn-ı Esâsî), which was developed under the leadership of Mithat Pasha and proclaimed in parliament on 23 December 1876, represents a political climax of this legal process in the sense of Habermas (Habermas, 1981b: 523). It was no coincidence that Mithat Pasha introduced this new constitution at the same time as installing a twochamber system comprising a Meclis-i Mebusan and Meclis-i Ayan. The influence of the ayans was thus also politically institutionalized under constitutional law.

\section{The Ottoman Guilds in Comparison with European}

The influence of the ayans was mainly based on the ability of their money power to mobilize in the economic system, the meritocratic principle of which was organized in the Ottoman Empire within the framework of the guilds. The European guilds, on the other hand, were from the beginning on in a vulnerable relationship with feudal structures and the Christian religion. There is a setback, for example, in England during the Reformation and in France during the French Revolution, but the guilds played a decisive role in Europe (Ogilvie, 2014: 171). In Europe the members of the guilds usually belonged to the elite. Guilds functioned as social networks in which social capital was coordinated through community trade and in which geographical, political, and military boundaries were abolished (Weber, 1980a: 752). They played a vital role in the monopolization of economic interests (Ogilvie, 2014: 173; Luhmann, 1997e: 830). "Without the consent of the guilds, no one could be imprisoned in Münster in the 15th century (...)." (Weber, 1980a: 775). Thanks to their own "internal courts" they were able to protect their members, train them in their centres, maintain relations with the political elite in their name, negotiate contracts and thus organize both domestic and foreign trade" (Ogilvie, 2014: 174, 178; Weber, 1980a: 62, 789). A guild typically generated a particularized trust among its own members, as insiders in the closed and multiplex social network of that guild. But broader economic growth requires a generalized trust that makes people willing to transact on an equal footing with everyone, even strangers" (Ogilvie, 2014: 186):

In the European guilds, this social integration was at the expense of those who could neither externalize their losses in the historical interdependence between politics, religion and business nor had a comparable network at their disposal with the help of which they could have made up a concession for their structural exclusion by the legal system (Weber, 1980a: 779). "No matter how numerous or large a town's guilds, guild members typically made up only a minority of inhabitants. Half the population was inherently excluded, since very few guilds allowed female members other than the second-class status permitted to masters' widows. Even for males, guild membership 
... (akademik, hakemli, indexli, uluslararası dergi)

usually required town 'citizenship', a costly privilege enjoyed by less than half the inhabitants of a typical premodern European town (...). Most guilds also excluded Jews, bastards, migrants, laborers, farmers, propertiless men, former serfs and slaves, gypsies, members of other guilds, adherents of minority religions, men of 'impure' ethnicity, and those who couldn't afford the admissions fees" (Ogilvie, 2014: 172).

The Ottoman guilds, on the other hand, arose mainly in cities where religion as a system of what-to-do was "the specific foreign body" (Weber, 1980a: 795). There were a number of metropolises in the Ottoman Empire such as Cairo, Mosul, Algiers, Damascus, Bursa and İstanbul. Faroqhi emphasizes that these cities were as well organized as the European cities of the 20th century (Faroqhi, 2000c: 702). Until the 17th century, the urban life of the Ottomans was also mainly supported by the structures of vakfflar (Faroqhi, 2000c: 705; Singer, 2008: 145). It was not until the 17th century that the guilds began to increasingly shape urban life. After that, the guilds assumed various functions in urban life, such as collecting taxes, quality control, setting prices and salaries, providing public services, assuming legal tasks, as well as social functions, such as mutual assistance through the use of the guilds as networks (Baer, 1970: 37). Because of these functions, they were treated as "semi-official agencies" according to Kuran (Kuran, 2000a: 43). Just as the waqf and the state were in a mutual communication, so too were the guilds "closely connected with the government. One of its principal raisons d'être was to serve as an administrate link between the ruling institution and the town population and as a means of supervision and control of this population by the rulers" (Baer, 1970: 49).

Guilds were called "lonca" in the Ottoman Empire, probably derived from the Spanish "lonja" (Bayram, 2012: 82). Therefore, Kuran assumes that the first Ottoman guilds were founded in the 17th century by Jewish immigrants from Spain (Kuran, 2000a: 45). Historically, they date back to the Islamic ahi and futuwwa movements (Lewis, 1937: 89; Taeschner, 1951: 554; Bayram, 2012: 84). On the other hand, Baer points out that the ahi and futuwwa were not intuitionally established and their members were not professionals (Baer, 1970: 28). Taking regional differences into account, their semi-professionalization did not occur until the first half of the 16th century (Baer, 1970: 49). Although the guilds were under Islamic influence when they were formed, the fact that they were organized under profane Sultanic and not sacred Khalifa legislation meant that they played the role of today's employers' or workers' associations, receiving state recognition in return for control and monopoly in an economic sector (Mahiroğullar1, 2008: 144, 147). "Ottoman officials offered the guilds an implicit bargain: in return for official recognition of their monopolies, and sometimes also their monopsonies, the guilds would submit to state supervision and avoid actions inimical to the vital economic interests of other protected groups. Government functionaries would keep guilds from encroaching on each other's economic domain; and the guilds themselves would respect the established market-sharing arrangements" (Kuran, 2000a: 45).

\section{Intermediate Reflection}

Just as solidarity was expected during the time of the Islamic prophet Muhammad in the framework of the voluntary zakât system and in the foundation and establishment phase of the Ottoman Empire this Islamic solidarity was given a state-backed institutional framework in the vakuflar, with the advent of modernity a next form of solidarity and organization had to be found. In the social structure according to segmental differentiation, the place of the individual in society was 
... (akademik, hakemli, indexli, uluslararası dergi)

determined by higher powers. The disputes and legal questions were not regulated according to abstract norms of rights, but within a sacred order according to analogies (Luhmann, 1997e: 636, 651). With the pressure resulting from the rationalization also through long-distance trade and wars, social equality and moral justice within the Islamic community (umma) had to be regulated more and more according to its egalitarian ethics, with which, in addition to analogy and reciprocity integration as a universalist principle of ethic or law based coordination and belonging system was increasingly applied. The codifications of existing legal systems into Islamic legislation can be traced back to this (Rohe, 2013: 22). Later, under the leadership of Sultan Süleyman I (r. 15201566), the profane land and taxation reforms were carried out, which is why he was given the nickname Kanuni (legislator) (Barkey, 1996b: 469; İnalc1k and Anhegger, 2000: 10). Significantly, this rationalization of the law was initially used in the new division of states. Kanuni's decrees made explicit that the law does not go back to a divine order, but is an instrument developed by people for living together, namely for social integration.

At the normative level, the need for integration was evident in the contradiction between the de facto performance of an ottoman for the establishment of a just Islamic society and the sacred attributions in favour of every Muslim. Within the Ottoman Empire and as a rule, only Muslims and men were able to found vakuflar. Within the development of social complexity, the state as a rational organization had to reward concrete achievements instead of religious promises, for which social inclusion had to be applied. Not only social Integration on the basis of magical and religious laws but inclusion according to achievement, performance and laws explicitly passed by statesmen and for state purposes. On the organizational level this transformation is documented especially by the differentiation between centre and periphery as well as between Islamic and Sultanic laws. This process took place incrementally (Akgündüz, 2009: 210; Barakat, 2015: 107). With the advent of modernity, this tension between these two types of coordination intensified once again. This is indicated by the introduction of Sened-i Ittifak and reforms during the Tanzimat phase, which was influenced by the French Revolution. Their most important actors, the ayans, demanded exclusion on the basis of their property and inclusion based of universal rights (Barakat, 2015: 104; Karpat 2006b: 25, 231).

This simultaneous inclusion and exclusion required a new organization and a new type of mechanism for coordinating joint action. The Ottoman guilds and the ayans as their representatives represented this new form of organization und solidarity in it. In contrast to vaklflar, the guilds were outside the official religious system, institutionally separated from the sphere of morality and explicitly founded for economic-rational purposes. In this respect there is a contrary development between vakıflar and guilds and between European and Ottoman guilds. While in Europe the guilds had the function to provide for exclusion according to the segmental principle of similarity and with modernity received a folkloristic function, in the Ottoman Empire not the guilds, but the vaklflar had this function. Vaklflar were legitimized as a form of land appropriation, land conquest and land cultivation in the name of Almighty God. Since the Ottoman Empire regarded itself as the empire of the Muslims and divided the world into a dar-ul islam (house/world of peace) and a dar-ul harb (house of war), the non-Muslims had no chance at all to serve God with the foundation of a vakif, i.e. to make a contribution to the spread of Islamic ethos. The non-Muslims were due to their religious affiliation not allowed to found a vakıf in the country of Islam. From this perspective they were structurally forced to found their own organization, institution and state. Because integration 
was understood during this time in its total sense; that is an individual is either integrated in the society of Muslim, dar-ul islam or he is on the side of dar-ul harb, the non-Moslems were from these normative points of view not integrated, although they were recognized in their millets and in that very sense included in the structure of Ottoman Empire. This is the reason, why they would only in their own state not only socially and politically integrated, but now functionally also included.

On the other hand, from the 17th century onwards, the Ottoman guilds established themselves particularly in the cities and had no positive structural relationship either with the Islamic land or military system. Within the Ottoman Empire, the vakıflar had the function of social exclusion. In Weber's sense, we can state that in the Ottoman Empire the vakıflar were ständisch and the guilds städtisch, urban (Weber, 1980a: 177, 533). In fact, the vaklflar were ideally organized according to the principle of diversity along ethnic groups (millet), while within an Ottoman guild functional differentiation determined the interactions between the actors. Membership to a guild as a society was self-selected on the basis of functional differentiation. As a result of this organizational typology, the president of a guild was elected on the basis of functional equality by his peers because of his abilities and skills, whereas the administrator of a vakıf was appointed for life by the founder because of his status and the loyalty of the aspirant (Schoenblum, 1999: 1207, 1221). What is more, the guilds were led primarily and superficially by non-religious people. Thanks to this, non-Muslims could not only participate, but also take a leading role in the rebellion of 1730 and 1740 (Olson, 1977a: 191, 202; Olson, 1979b: 78).

The guilds enabled the actors to challenge the state with rebellions also by winning over the barracked power, namely the Janissaries to their cause. Janissaries were considered to be the property of the state. After the collapse of the land and military system and the rise of the ayans, the janissaries, whose association was also based on the principle of functional equality, consequently cooperated less and less with the founders of vakıflar and more and more with the members of the guilds. Here, they solidarized with functionally equal, wo were their religious uncompanions (Weber, 1980a: 385, 739, 755). In the course of time, they began to act themselves, or they joined traders, using the guilds as the networks (Faroqhi, 2000c: 707; Çelik, 2019: 1689). In the Ottoman Empire, thanks to the guilds, a new form of social network was established, whose actors entered into an inclusive solidarity with each other in competition against the patrimonial structures.

\section{The Evolution of Complementarity}

This new gathering under the sign of simultaneous integration and inclusion can best be described by the term of complementarity (Bohr, 1937: 296; Plotnitsky, 1994: 68; Reich, 2010: 4). To begin with, contingency first mentioned by Durkheim is to be described here, according to whom not only (un)morality, society, but also our concepts for its comprehension run from the simple to the complex (Durkheim, 1981a: 20, 306, 469; Durkheim, 1991c: 83, 169). The concepts of analogy, integration, inclusion and complementarity reflect this differentiation. In all these cases, what captured is the type of the action. They are the answers of the corresponding social formations to the same question; how are ego's expectations of age bundled in an ideal-typical way? In that sense, they are coordination mechanism.

Habermas defines with the reference of Durkheim the process of this transition as a change of form, while in systems theory the same process is discussed under the concept of evolution 
... (akademik, hakemli, indexli, uluslararası dergi)

(Habermas, 1981b: 139, 259; Luhmann, 1997e: 556; Luhmann, 1993c: 240). Habermas first distinguishes between the increase in complexity of the system and the rationalization of the norm, and then mediate them with his theory of communicative action under the concept of system and social integration. Luhmann, on the other hand, renounces this integration, instead assumes an inclusion demand by the society (Luhmann, 1997e: 618; Luhmann, 1995d: 237) and defines the transition as a differentiation in the sense of "maintaining cohesion under the condition of growth" (Luhmann, 1997e: 596). In both cases, a development from the simple to the complex is postulated, albeit with different intentions. While Habermas expected this change from the legal system, Luhmann left this achievement to the organizations and their symbolic media like power and money.

From both perspectives, there is a tendency towards higher abstraction in every functional system. Consequently, temporally and socially, the form can be separated from the content, the person from her office, legality from legitimacy, domination from morality. This in turn contributes to fact that this separation and differentiation can be made reflexive through symbolic reproduction in the lifeworld, in personality, in society, in organizations and in communication itself. In the writings of Durkheim, Weber, Parsons, Luhmann and Habermas, this development can be brought together with moral, law and property types as well as the differentiation of functional systems (Durkheim, 1981a: 282; Weber, 1980a: 456; Weber, 1988d: 551; Parsons, 1937a: 43; Parsons, 1951b: 15; Luhmann, 1997e: 190; Habermas, 1981a: 320; Habermas, 1998d: 32, 472). Within the legal system, the law based asymmetry was first used and only later the contract law based symmetry was used as the mechanism of action coordination (Luhmann, 1993c: 66, 151, 266, 310). Weber's ideal-typical distinction between ethics of law and ethics of responsibility, as well as Durkheim's concept of contract solidarity, are based on this insight (Weber, 1988d: 550; Durkheim, 1988b: 263, 450). The communication media such as power, money and right also correspond with this.

Using the logic of ideal type, integration can be defined as the mechanism of action coordination of sacral law based on community and inclusion as the bundling of expectations in societies with modern law system (Luhmann, 1997e: 634, 743; Habermas, 1981b: 248). On the one hand, the norm, structure and action based concept of integration and the function and system based concept of inclusion without any reference to a higher power, is sufficient to grasp the mode of action according contractual solidarity, which implies a process of insertion into one another to form a whole, such as the contractual agreement between two expectations at the optimal price for both sides. On the other hand, neither integration nor inclusion is sufficient complex enough to capture a coordination according to a communicative joint action under an abstract principle, which is why complementarity is proposed here.

In comparison, complementarity indicates a more complex structure and function (Reich, 2010: 35). According to Luhmann, complementarity exists when the ego has a certain expectation of alter and alter has expected this expectation on his part (Luhmann, 1981b: 362). It corresponds to the logic of reciprocity. By contrast, Parsons did not understand complementarity to mean a correspondence between the expectations of ego and alter, but rather an orientation from ego to alter expectations, in which the perspective of "the generalized other" was encompassed (Mead, 1913: 152; Parsons, 1951b: 24, 140, 327; Parsons and Shils, 1962: 56). The idea of the generalized 
... (akademik, hakemli, indexli, uluslararası dergi)

other is normative concept in the sense of integration according to a higher norm. This understanding has the pragmatic advantage that the adoption of the ethical principles and their change is embedded within a cultural sphere and is sought here through the individual socialization process in the role structure, so that without a dissonance in stringency it can be connected to Habermas' view of action theory. For Habermas, the legitimacy of social order presupposes the viewpoint of the Neuter -the current uninvolved - who represents the abstract principle of the general norms and in that very sense the generalized other (Habermas, 1991c: 143). Consequently, Habermas understands double contingency as the double contingent understanding of communicatively acting actors to achieve a common definition of the situation under the condition of consensus (Habermas, 1981b: 392). Complementarity is therefore understood here to mean the orientation of the ego towards the expectations of alter under a publicly legitimized norm, for which sociologically the organizations come into question as the place of manifestation of this orientation, in the sense of "cathetic mode of orientation" (Parsons and Shils, 1962: 5).

With this concept of complementarity it can now be explained that in the Ottoman Empire a functional transition took place at the organizational level without directly affecting the structures, institutions of society. For as long as functional differentiation followed the existing normative orientation, the resulting disturbances and innovations could be isolated, decoupled from one another. Stability was sought in the normative orientations, and as long as this orientation guided the actors' search for change, the two levels, namely the society and organization were somehow coupled. On the other hand, social stability despite the change under the modern law on the organizational and societal level can be explained certainly and best not with reciprocity, integration and inclusion but with the complementarity: the orientation on the organizational level was delegated to functions and on the social and societal level to law, such liberal constitutionalism with individual autonomy in Europa. This coordination of expectations despite divergence interests and ideas is called complementarity.

That is the peculiarity of modernity. This lies in the fact that here the normative demand for a change from symmetrical reciprocity to asymmetrical integration, inclusion and from them to complementarity was transferred, which is justified by its own logic. In it, system and social integration or inclusion and exclusion are understood as the two sides of a single discourse society, in which all actions can be ranked according to the jointly legitimatised principle (Habermas, 1981a: 118, 380). The coordination of social system according to this principle is called here complementarity. But, contrary to Weber's assumption the moments of successful coordination of all actions according to a socially legitimized principle belong neither alone to modernity nor exclusively to a certain culture. This thesis was confirmed in the transition of the institution from vakiflar to the guilds.

\section{Conclusions}

Instead of assuming a decay of the vakıflar and its dysfunctionality as a taxation system their transformation was explained by complementarity that was carried by the corresponding economic order (capitalism), organization (guilds), and norm (modernity). Thus, with the emergence of modernity in the Ottoman Empire, solidarity was no longer sought on the basis of ethnic-ethical origin in a vakıf, but rather, based on the interests of its members, organized within the framework of guilds. Vakıflar were determined centrally and administered decentral. On the other hand, the 
... (akademik, hakemli, indexli, uluslararası dergi)

guilds no longer fitted neither in its normative expectation nor in the structure of geographical distinction between the centre and the periphery. Like vaklflar, guilds were organized around socially scarce goods, but in contrast to vaklflar, guilds were no longer founded and administered according to sacred morals, but on the basis of quasi-private property according to the modern legal system.

At the actors' level, we can see this differentiation in the fact that the guilds as an organization were led by their managers, whereas vakıflar were still run by their owner. Likewise, the managers in the guilds did not only belong to the Islamic faith. The members of other millet could also be managers in the guilds. The Ottoman guilds differed from Islamic vaklflar in that sense, that the guilds were organized around a scarce good, which was not simply given like the land, but had to be acquired by a personal achievement. As a result, the recipients of the right no longer secured social solidarity within the framework of transcendent order in the vakuflar, but based on their function in the guilds. Their structures accommodated the lifestyles of many people. For the craftsmen, soldiers, bureaucrats and peasants the guilds were better places because their membership was independent of their religious, educational, gender and linguistic backgrounds, and only because of their function as bankers, teachers, mason etc. In guilds the owners, contractors and addressees of the law came together. In the absence of a "critically discussing public", the guilds assume the function of an organization, in which the actors span a dense network of public communication (Habermas, 2013f: 13).

The most important actors of this phase within the Ottoman Empire are the ayans. Although the Ottoman Empire lacked an absolutely personal property right that could in principle be freely sold, the rise of the ayans had led to the family property in the form of vakiflar being replaced in principle by a quasi-private property under the Treaty of Sened-i Ittifak. The ayans as actors and the guilds as organizations, were superficially neutral in their religious and/or moral orientations. But everybody was aware of the instrumental character of this neutrality. In the 19th century they were able not only to defend themselves effectively against the state but also to expand their land and power accumulation with the accumulation of capital, so that only ayans could be considered for production for the large domestic markets and abroad. These local lords producing now for the world market entered into contracts with European partners thanks to the guild structures.

In summary, guilds are the institutions of diversity in Europe and the institutions of inequality in the Ottoman Empire. This difference also illustrates that the functions take a different form depending on the politico-legal structures; in Ottoman Empire there were no trade unions with an organizational power. Workers went into coalition with other politico-social groups against state power in guilds, which did not have a direct normative link to the state like vakuflar, nor did they belong to functional solidarity like trade unions. Rather, within the Ottoman Empire, they represented precisely the organizational form through which the transition from integration to inclusion was coordinated with each other under a common principle. On the other hand, the workers in the European cities could organize themselves into trade unions, which is why the guilds here took over the function of vakiflar that they had in the Ottoman Empire. In both cases, diversity was put into communication with equality, but in two different organizations with similar functions. 


\section{Bibliography}

(akademik, hakemli, indexli, uluslararası dergi)

Ahbab, Y. (2017). „Kalkandelen Para Vakıfları.“Journal of Ottoman Civilization Studies, 3(5),49-71. URL: https://dergipark.org.tr/en/pub/osmed/issue/28672/309239 [10.03.2021].

Akçay, C. (2019). "Yeni Vakıfların İşlevselliği: Seçilmiş Vakıflar İçin bir İnceleme,” Akademi Sosyal Bilimler Dergisi, 7(20),58-81. URL: https://dergipark.org.tr/tr/pub/asbider/issue/54336/737844 [10.03.2021].

Akdağ, M. (1999). Türk Halkının Dirlik ve Düzenlik Kavgası. Celali Isyanları. Ankara: Barış.

Akgündüz, A. (2002). “Osmanlı Hukukunda Vakıflar, Hükümleri ve Çeşitleri”. Türkler, (10),447-460.

Akgündüz, A. (2009). 'Shari' ah Courts and Shari'ah Records: The Application of Islamic Law in the Ottoman State." Islamic law and society, 16 (2), 202-230.

Anderson, B. (1983). Imagined communities: reflections on the origin and spread of nationalism. London: Verso.

Arendt, H. (1992). Vita activa oder Vom tätigen Leben. München: Piper.

Baer, G. (1970). “The Administrative, Economic and Social Functions of Turkish Guilds.” International Journal of Middle East Studies, 1(1), 28-50. DOI: https://doi.org/10.1017/S0020743800023898 [10.03.2021].

Baldwin, D.A. (1971). “Money and Power.” The Journal of Polities (33): 578-614.

Barakat, N. (2015). "Regulating Land Rights in Late Nineteenth-Century Salt: The Limits of Legal Pluralism in Ottoman Property Law." Journal of the Ottoman and Turkish Studies Association, 2(1),101-119. URL: https://www.jstor.org/stable/10.2979/jottturstuass.2.1.101 [10.03.2021].

Barkan, Ö. L. (1942). “Osmanlı İmparatorluğunda bir Îskân ve Kolonizasyon Methodu olarak Vakıflar ve Temlikler I. İstila Devirlerinin Kolonizatör Türk Dervişleri ve Zâviyeler.” Vakıflar Dergisi, (2),279353.

Barkey, K. (1994a). Bandits and bureaucrats: The Ottoman route to state centralization. Ithaca: Cornell University Press.

Barkey, K. (1996b). "In different times: Scheduling and social control in the Ottoman Empire, 1550 to 1650." Comparative Studies in Society and History, 38(3),460-483. DOI: https://doi.org/10.1017/S0010417500020028 [10.03.2021].

Bayram, S. (2012). „Osmanlı Devleti’nde Ekonomik Hayatın Yerel Unsurları: Ahilik Teşkilatı ve Esnaf Loncalar1.“ İstanbul Üniversitesi ilahiyat Fakültesi Dergisi, 0(21),81-115. URL: https://dergipark.org.tr/tr/pub/iuilah/issue/983/11077 [10.03.2021]. 
... (akademik, hakemli, indexli, uluslararası dergi)

Berkes, N. (1964). The development of secularism in Turkey. Montreal: Mc Gill University Press.

Bohr, N. (1937). "Causality and Complementarity.” Philosophy of Science, 4(3),289-298.URL: https://www.journals.uchicago.edu/doi/10.1086/286465 [10.03.2021].

Bulut, M. and Korkut, C. (2016). „A Comparison Between Ottoman Cash Waqfs (CWs) and Modern Interest-free Financial Institutions." Vakıflar Dergisi, (46),23-45. URL: https://dergipark.org.tr/en/download/article-file/268925 [10.03.2021].

Cengiz A. (2019). "Yeni Vakıfların İşlevselliği: Seçilmiş Vakıflar İçin bir İnceleme,” Akademi Sosyal Bilimler Dergisi, 7(20),58-81. URL: https://dergipark.org.tr/tr/pub/asbider/issue/54336/737844 [10.03.2021].

Çelik, B. (2019). "Yeniçerilerin Esnaflaşmasında Orducu Görevinin Rolüne Dair Bazı Tespitler.” Belgi Dergisi, 2(18): 1683-1700.URL: https://doi.org/10.33431/belgi.525956 [10.03.2021].

Çizakça, M. (2019). "İktisat Tarihi Açısından Vakıflar [Waqfs from the Perspective of History of Economics]." Vaklflar Dergisi, 80 (80th Year Special Issue),74-84. URL: https://doi.org/10.16971/vakiflar.586069 [10.03.2021].

Demir, A. (2017). „Eine rechtssoziologische Analyse des islamischen waqf-Systems.“ In: The Electronic Journal of Islamic and Middle Eastern Law (EJIMEL), (5),55-79.

URL:http://www.zora.uzh.ch/138126/1/A.Demir Eine rechtssoziologische Analyse des islamische n_waqf-Systems.pdf [10.03.2021].

Doğan, M. (2019). “Osmanlı Tımar Sistemi’nde Muasırlarının Gözünden Değişme ve Çözülme.” Çankırı Karatekin Üniversitesi Sosyal Bilimler Enstitüsü Dergisi, 10 (2),149-173. URL: https://dergipark.org.tr/tr/pub/jiss/issue/50416/637264 [10.03.2021].

Durkheim, E. (1981a). Die elementaren Formen des religiösen Lebens. Frankfurt a.M.: Suhrkamp.

Durkheim, E. (1988b). Über soziale Arbeitsteilung: Studie über die Organisation höherer Gesellschaften. Frankfurt a.M.: Suhrkamp.

Durkheim, E. (1991c). Physik der Sitten und des Rechts. Vorlesungen zur Soziologie der Moral. Frankfurt a.M.: Suhrkamp.

Faroqhi, S. (1976a). “The Tekke of Hacı Bektaş: Social Position and Economic Activities.” International Journal of Middle East Studies, 7(2),183-208. DOI: https://doi.org/10.1017/S0020743800023175 [10.03.2021].

Faroqhi, S. (1981b). Der Bektaschi-Orden in Anatolien: vom späten fünfzehnten Jahrhundert bis 1826.

Wien: Verlag des Institutes für Orientalistik der Universität Wien. 
... (akademik, hakemli, indexli, uluslararası dergi)

Faroqhi, S. (2000c). “Krizler ve Değişim.” İnalcık, H. and Quataert, D.(Ed.), Osmanlı İmparatorluğu’nun Ekonomik ve Sosyal Tarihi. Vol. II: 1600-1914 (p. 545-758). İstanbul: Eren.

Habermas, J. (1981a). Theorie des kommunikativen Handelns, Band I: Handlungsrationalität und gesellschaftliche Rationalisierung. Frankfurt a.M.: Suhrkamp.

Habermas, J. (1981b). Theorie des kommunikativen Handelns, Band II: Zur Kritik der funktionalistischen Vernunft. Frankfurt a.M.: Suhrkamp.

Habermas, J. (1991c). Erläuterungen zur Diskursethik. Frankfurt a.M.: Suhrkamp.

Habermas, J. (1998d). Faktizität und Geltung: Beiträge zur Diskurstheorie des Rechts und des demokratischen Rechtsstaates. Frankfurt a.M.: Suhrkamp.

Habermas, J. (1999e). Die Einbeziehung des Anderen. Studien zur politischen Theorie. Frankfurt am Main.

Habermas, J. (2013f). Strukturwandel der Öffentlichkeit. Untersuchungen zu einer Kategorie der bürgerlichen Gesellschaft. Frankfurt a.M.: Suhrkamp.

Heper, M. (1980). "Center and periphery in the Ottoman Empire: with special reference to the nineteenth century." International political science review, 1(1),81-105. URL: www.jstor.org/stable/1600742 [10.03.2021].

Hoexter, M. (1998). "Waqf Studies in the Twentieth Century: The State of the Art." Journal of the Economic and Social History of the Orient, (41) 474-495.

İnalcık, H. and Anhegger, R. (2000). Kânûnnâme-i Sultâni ber mûceb-i ’örf-i’ Osmânî. II. Mehmed ve II. Beyazid devirlerine ait yasaknâme ve kânûnnâmeler. Ankara: Türk Tarih Kurumu.

Kafadar, C. (1995). Between two worlds: the construction of the Ottoman state. Berkeley: University of California Press.

Karpat, K. H. (1972a). “The transformation of the Ottoman state, 1789-1908.” International journal of Middle East studies, 3(3),243-281. DOI: https://doi.org/10.1017/S0020743800025010 [10.03.2021].

Karpat, K. H. (2006b). Osmanlı'da Degisim, Modernlesme ve Uluslaşma. Ankara: İmge.

Karpat, K. H. (2009c). Osmanlı’dan Günümüze Elitler ve Din. İstanbul: Timaş.

Kayaoğlu, İ. (1978). "Vakfın Menşei Hakkındaki Görüşler.” Vakıflar Dergisi, (11),49-55. URL: http://hdl.handle.net/11352/1146 [10.03.2021].

Köprülü, M. F. (1938). "Vakıf Müessesesi ve Vakıf vesikalarının tarihi ehemiyeti.” Vakıflar Dergisi, (1),1-6.

Kuran, T. (2000a). "Islamic Influences on the Ottoman Guilds.” Çicek, K. (Ed.), The Great Ottoman-

Turkisch Civilization 2. Economy and Society (p. 43-59). Ankara: Yeni Türkiye Yayınları. 
... (akademik, hakemli, indexli, uluslararası dergi)

Kuran, T. (2001b). "The Provision of Public Goods under Islamic Law: Origins, Impact, and Limitations of the Waqf System.” Law \& Society Review, 35(4),841-897. URL: https://www.jstor.org/stable/3185418 [10.03.2021].

Kuran, T. (2016c). "Legal Roots of Authoritarian Rule in the Middle East: Civic Legacies of the Islamic Waqf." American Journal of Comparative Law, 64(2),419-454. URL: https://doi.org/10.5131/AJCL.2016.0014 [10.03.2021].

Lewis, B. (1937). “The Islamic Guilds.” The Economic History Review, 8(1),20-37. URL: https://doi.org/10.1111/j.1468-0289.1937.tb01703.x [10.03.2021].

Lockwood, D. (1964). “Social Integration and System Integration.” Zollschan, G. K. and Hirsch, W. (Ed.), Social Change: Explorations, Diagnoses and Conjecture (p. 370-383). New York: Wiley.

Luhmann, N. (1972a). Funktionen und Folgen formaler Organisation. Berlin: Duncker \& Humblot.

Luhmann, N. (1981b). Ausdifferenzierung des Rechts: Beiträge zur Rechtssoziologie und Rechtstheorie. Frankfurt a.M.: Suhrkamp.

Luhmann, N. (1993c). Das Recht der Gesellschaft. Frankfurt a.M.: Suhrkamp.

Luhmann, N. (1997e). Die Gesellschaft der Gesellschaft. Frankfurt a.M.: Suhrkamp.

Luhmann, Niklas (1995d): Die Soziologie und der Mensch. Opladen: Westdeutscher Verlag.

Luz, N. (2014). The Mamluk city in the Middle East: history, culture, and the urban landscape. New York: Cambridge University Press.

Mahiroğulları, A. (2008). „Selçuklu/Osmanlı döneminde kurumsal bir yapı: Ahilik/Gedik teşkilatı ve sosyoekonomik işlevleri.“ Sosyal Siyaset Konferansları Dergisi, 0(54),139-154. URL: https://dergipark.org.tr/tr/pub/iusskd/issue/899/10100 [10.03.2021].

Mardin, S.. (1969a). "Power, civil society and culture in the Ottoman Empire." Comparative studies in society and history, 11(3),258-281. DOI: https://doi.org/10.1017/S0010417500005338 [10.03.2021].

Mardin, Ş. (1992b). Türkiye 'de Toplum ve Siyaset. Makaleler 1. İstanbul: İletişim.

Matuz, J. (2010). Das Osmanische Reich: Grundlinien seiner Geschichte. Darmstadt: Primus Verlag.

Mead, G. H. (1913). “The Social Self.” Journal of Philosophy, Psychology and Scientific Methods, (10), 374-380.

Morgan, C. (2001): "Islam and Civil Society: The Waqf." The Good Society, 10(1),21-24.URL: https://www.jstor.org/stable/20710998 [10.03.2021]. 
... (akademik, hakemli, indexli, uluslararası dergi)

Mundy, M. and Smith, R. S. (2007). Governing property, making the modern state: law, administration and production in Ottoman Syria. London: Tauris.

Nizri, M. (2015). "Defining Village Boundaries at the Time of the Introduction of the Malikane System: The Struggle of the Ottoman State for Reaffirming Ownership of the Land." Journal of the Ottoman and Turkish Studies Association, 2(1),37-57. URL: https://www.jstor.org/stable/10.2979/jottturstuass.2.1.37 [10.03.2021].

Ogilvie, S. (2014). "The Economics of Guilds.” Journal of Economic Perspectives, 28(4),169-92.URL: https://www.aeaweb.org/articles?id=10.1257/jep.28.4.169 [10.03.2021].

Olson, R. W. (1977a). "Jews, Janissaries, Esnaf and the Revolt of 1740 in İstanbul: Social Upheaval and Political Realignment in the Ottoman Empire." Journal of the Economic and Social History of the Orient, 20(2),185-207. URL: https://www.jstor.org/stable/3631777?seq=1 [10.03.2021].

Olson, R. W. (1979b). "Jews in the Ottoman Empire in Light of New Documents." Jewish Social Studies, 41(1),75-88. URL: https://www.jstor.org/stable/4467038?seq=1 [10.03.2021].

Ozil, A. (2019). "Whose Property Is It? The State, Non-Muslim Communities, and the Question of Property Ownership from the Late Ottoman Empire through the Turkish Nation State." Journal of the Ottoman and Turkish Studies Association, 6(1),211-235. URL: https://www.jstor.org/stable/10.2979/jottturstuass.6.1.12 [10.03.2021].

Parsons, T. (1937a). The structure of social action: a study in social theory with special reference to a group of recent European writers. New York: The Free Press.

Parsons, T. (1951b). The Social System. London: Routledge.

Parsons, T. (1960c). "Pattern Variables Revisited: A Response to Robert Dubin.” American Sociological Review, 25(4),467-483. URL: https://www.jstor.org/stable/2092932?seq=1 [10.03.2021].

Parsons, T. and Edward A. S. (1962). Toward a General Theory of Action. Cambridge MA: Harvard University Press.

Peirce, L. P. (1993). The imperial harem: women and sovereignty in the Ottoman Empire. New York, N.Y.: Oxford University Press.

Plotnitsky, A. (1994). Complementarity. Anti-Epistemology after Bohr and Derrida. Durham and London.

Quataert, D. (2000). Osmanl Imparatorluğu 1700-1922 [Org: The Ottoman Empire, 1800-1922]. İstanbul: İletişim.

Reich, H. K. (2010). Developing the Horizons of the Mind. Relational and Contextual Reasoning and the 
-.. (akademik, hakemli, indexli, uluslararası dergi)

Resolution of Cognitive Conflict. Cambridge: Cambridge University Press.

Rohe, M. (2013). Das islamische Recht: eine Einführung. München: Beck.

Rumpf, C. (1996). Das türkische Verfassungssystem: Einführung mit vollständigem Verfassungstext. Harrassowitz Verlag: Wiesbaden.

Sadat, D. R. (1972). "Rumeli Ayanlar1: The eighteenth century.” The journal of modern history, 44(3),346363.

Saraçoğlu, M. S. (2015). "Economic Interventionism, Islamic Law and Provincial Government in the

Ottoman Empire." Journal of the Ottoman and Turkish Studies Association, 2(1),59-84. URL: https://www.jstor.org/stable/10.2979/jottturstuass.2.1.59 [10.03.2021].

Schoenblum, J. A. (1999). "The Role of Legal Doctrine in the Decline of the Islamic Waqf: A Comparison with the Trust." Vanderbilt Journal of Transnational Law, (32),1191-1227. URL: https://heinonline.org/HOL/LandingPage?handle=hein.journals/vantl32\&div=40\&id=\&page= [10.03.2021].

Singer, A. (2008). Charity in Islamic Societies. Cambridge: Cambridge University Press.

Suleiman, H. (2016). “The Islamic Trust waqf: A Stagnant or Riviving Legal Institution?” Electronic Journal of Islamic and Middle Eastern Law (EJIMEL), 4(23),25-43. URL: https://www.zora.uzh.ch/id/eprint/123754/1/Suleiman_Haitam_Waqf_Published.pdf [10.03.2021].

Taeschner, F. (1951). "Das bosnische Zunftwesen zur Türkenzeit (1463-1878).” Byzantinische Zeitschrift, $44(1-2), 551-559$.

Uzunçarş111, İ. H. (1941). “Gazi Orhan Bey Vakfiyesi.” Belleten, 5(19):227-288. URL: https://belleten.gov.tr/tam-metin-pdf/665/tur [10.03.2021].

Van Leeuwen, R. (1999). Waqfs and Urban Structures: The Case of Ottoman Damascus. Leiden: Brill.

Weber, M. (1980a). Wirtschaft und Gesellschaft: Grundriss der verstehenden Soziologie. Tübingen: Mohr.

Weber, M. (1985b). „Die ,Objektivität’ sozialwissenschaftlicher und sozialpolitischer Erkenntnis.“ In: Winckelmann, Johannes (Hrsg./Ed.): Gesammelte Aufsätze zur Wissenschaftslehre (p. 146-214). Tübingen: Mohr.

Weber, M. (1986c). Gesammelte Aufsätze zur Religionssoziologie. Tübingen: Mohr.

Weber, M. (1988d). Gesammelte politische Schriften. Tübingen: Mohr. 